\title{
Improving the Competitiveness of Exporting Enterprises: A Case of Kien Giang Province in Vietnam
}

\author{
Minh Tuan NGUYEN ${ }^{1}$, Bui Thanh KHOA ${ }^{2}$
}

Received: April 06, 2020 Revised: April 18, 2020 Accepted: May 07, 2020

\begin{abstract}
Economic integration is an indispensable trend in all countries. However, besides the advantages that economic integration brings, there are also disadvantages, such as competition between businesses among states in export activities. Vietnam is a developing country with many advantages, especially, the seafood exporting industry. However, with competitive pressure as well as strategic constraints, Vietnamese seafood exporters still face many difficulties. Therefore, the case study of the Kien Giang province of Vietnam is used to analyze the factors affecting the competitiveness of seafood exporting enterprises. The study applied quantitative research methods with a survey of 350 seafood exporting enterprises in Kien Giang province to achieve the research objectives. The research results identified eleven key factors affecting the competitiveness of seafood exporting enterprises, including (1) vision and strategy of leader; (2) human resources management capability; (3) organization capability; (4) customer-responsive marketing capability; (5) relationship management capability; (6) technical capability; (7) competitors reaction capability; (8) business environment adoption capability; (9) financial capability; (10) products and services innovation capability; and (11) branding management. The research results provided the basis to propose some managerial implications to improve the competitiveness of exporting enterprises in the context of the global economic integration.
\end{abstract}

Keywords : Competitiveness, Exporting Enterprise, Economic Integration, Strategic Management, Vietnam.

JEL Classification Code: M10, M16, L10.

\section{Introduction}

Competition is typical of the market economy when the supply-demand and the price of goods are the decisive factors. Enterprises participating in production and business activities want to have the most favorable business conditions, such as minimizing input costs. Therefore, enterprises must find cheap raw materials, improve labor productivity, and improve machinery as well as equipment. The result of competition is to promote economic development and create more benefits

${ }^{1}$ First Author. Associate Professor, Lecturer, Faculty of Business Administration, Banking University - Ho Chi Minh City, Vietnam. Email: tuannm@buh.edu.vn

${ }^{2}$ Corresponding Author. Ph.D. Student, Graduated School, Ho Chi Minh City Open University, Vietnam [Postal Address: No. 20, Street 8, Quarter 2, Hiep Binh Chanh Ward, Thu Duc District, Ho Chi Minh City, 721400, Vietnam] Email: khoabt.15ab@ou.edu.vn; khoadhcn@gmail.com

(c) Copyright: The Author(s)

This is an Open Access article distributed under the terms of the Creative Commons Attribution Non-Commercial License (http://Creativecommons.org/licenses/by-nc/4.0/) which permits unrestricted noncommercial use, distribution, and reproduction in any medium, provided the original work is properly cited. for society, as well as consumers, where the enterprises will supply more selected products or services and use better products and services. Competition in the economy is to gain market share (Porter, 1980). The essence of competition is to seek profit, which is higher than the average profit that the business is generating. The result of the competition process is the equilibrium of earnings in the industry in the direction of profound improvement leading to reduced price consequences. The competitiveness demonstrates the real power and advantages of the enterprises compared to competitors (Lu et al., 2008).

In the context of economic integration, competition between businesses on a global scale is indispensable, and this competitive pressure affects all industries, not just Vietnam (Nguyen \& Ngoc, 2020; Kim, 2005). Considered from a macro perspective, international economic integration or the signing of free trade agreements (hereafter FTA) bring for businesses not only opportunities, but also many challenges, for example, the Comprehensive and Progressive Agreement for Trans-Pacific Partnership (hereafter CPTPP). The FTAs opened up opportunities for Vietnamese enterprises to access new markets and have the opportunity to diversify 
sources of input materials (such as yarns in the textile industry). Besides, enterprises also face challenges, such as the integration policies of Vietnam is not yet complete, and the weak competitiveness of some sectors, i.e., services, advertising, agricultural products, i.e., pork, chicken, and seafood.

Based on the 2019 Global Competitiveness Report, Vietnam ranked 67 out of 141 countries and territories, up to ten places (77) from 2018 (Schwab, 2019). Although there has been an improvement in competitiveness ranking, Vietnam's position is still low compared to many countries. One of the factors affecting the low ranking is the export competitiveness of Vietnamese enterprises. Similar to other developing countries, although possessing superior capabilities over developed countries, Vietnam has not been able to make a difference in exported goods, especially seafood product. Vietnam's water area is more than three times the land area; the coastline is over 3,260 km (ranked 27 th in terms of coast length among 157 coastal and island nations in the world) and billions of 6-fold frontage to the sea. These have excellent advantages in developing the marine economy and international economic integration (Minot, 1998).

The study paves the way for the development of strategic planning for enterprises as well as the development of the country (Lall, 2001). Vietnam's seafood industry has proliferated. Seafood exports have become one of the four sectors with the most foreign currency earnings for the country. In that success, the role of seafood exporting enterprises is the central factor. However, the development of fishery enterprises in the Mekong Delta in general, and Kien Giang province, in particular, has not been commensurate with the potential. According to Porter (2008), competitiveness can help businesses stand firm in the market, expand market share, and increase profits. Competitiveness is also the ability to perform better than competitors in achieving the most crucial goal of profit, i.e., creating as well as maintaining profits in a rapidly changing environment (Ambrosini \& Bowman, 2009).

Many studies are measuring the dimensions of competitiveness, i.e., Guan et al.(2006), Karim et al.(2008), Rojalka (2009), and Salloum (2013). The above studies are about understanding competitiveness in various aspects from measurement methods, to measurement perspectives from different countries. The business efficiency will increase if the company is more competitive through the improvement of possible factors, which will impact on the competitiveness. However, in-depth studies in this direction are quite limited, especially in seafood processing and exporting enterprises. This study is to investigate the factors impacting on the competitiveness of Vietnamese seafood exporting enterprises, through the case of the Kien Giang province, which is a representative case for Vietnam. From that, the study draws some implications to increase the competitiveness of Vietnamese exporting in the economic integration stage.

\section{Literature Review}

\subsection{Competitiveness (COMP)}

The term "competitiveness" has been widely used, but there are still many different views about it. Therefore, the measure of enterprise competency has not been strictly defined and popularized. For example, according to traditional trade theory, the competitiveness of enterprises is considered through comparative advantage in production costs and productivity. According to the aggregate views of Martin et al. (1991), the competitiveness is the ability to create and maintain profits, market share in domestic and foreign markets, labor productivity indicators, technology, the total productivity of production factors, the cost for research and development (R\&D), product quality and differentiation, input costs. From the strategic management viewpoint of Porter (2008), competitiveness is the ability to create products with unique technology processes to create high added value following customer needs, with low cost, high productivity to increase profits.

\subsection{Antecedents of Competitiveness}

From Porter's research (1980, 1990, 2003), Thompson et al. (2006), and related studies, the authors proposed a research model of internal factors to impact the competitiveness of exporting enterprises in Kien Giang.

(1) Vision and strategic leadership (VSL): Vision and strategic leadership are to demonstrate a clear and inspiring vision for the organization and team, and determine the best way to move towards the bank's vision, mission, and goals while taking into account the needs of all stakeholders. It demonstrate a global perspective and understanding of global markets and global thinking (Nguyen et al., 2019; Kivipõld \& Vadi, 2010)

(2) Human resources management capability (HRMC): The managers must make human resource planning, management, and talent development an integral part of bank management and administration. They must encourage and empower the employees themselves in the enterprise (Bolden, 2011). Human resources management capability is demonstrated by ensuring that the organizational and departmental direction is capable of managing risks and changing continuously in the human resource, while continuously striving for excellence and continuous improvement (Morrill, 2007).

(3) Organization capability $(O C)$ : Organization capability (strategic planning, planning, operational management) 
is important in improving operational efficiency, greatly affecting the competitive competence of the business. Corporate governance is defined as the organization of the operating system for businesses (board of directors, a board of directors and departments) and functions related to roles of the management process, implementation of strategies, and goals to ensure high performance (Ho, 2005).

(4) Customer responsiveness capability (CURC): Currently, marketing has shifted from a mixed marketing model to a relationship marketing model. This capability builds the quality of relationships between the business and the customer. Customer responsiveness capability helps businesses implement marketing programs more effectively. It is this capability that will help businesses capture changes in customers' needs for products and services they provide, thereby having a basis for offering new and more appropriate products and services (Benedetto \& Crawford, 2008).

(5) Relationship quality (RQ): Relationship quality shows the extent to which businesses achieve the quality of relationships with customers, suppliers, distributors, and appropriate governmental levels (Krasnikov \& Jayachandran, 2008). The quality of the relationship is considered as a list of significant relationship outcomes, and it reflects the power that the relationship can meet the needs and expectations of the stakeholders in the relation (Smith, 1998). HennigThurau and Klee (1997) argued that relationship quality is the appropriate level of relationships in order to meet the needs of customers who accompany the relationship.

(6) Innovation technology capability (ITC): Guan et al. (2006) have confirmed the close internal relationship between technology improvement and competitiveness. The results show that enterprises can improve their competitiveness through technological innovation. Kocoglu et al. (2012), Lai and Lin (2012) studied the three-dimensional correlation between technology improvement and technology learning, and the impact of technology learning on company performance innovation.

(7) Competitor responsiveness capability (CORC): Competitor responsiveness capability demonstrates the firm's monitoring of competitors' business activities (Homburg et al., 2007). Moreover, being proactive is the way that businesses often conduct their strategic planning and implementation according to a development roadmap and goals in each stage of development of enterprises. This capability is how to create a proactive position for business in responding to competitors (Kohli \& Jaworski, 1990).

(8) Responsiveness to the change of the macroenvironment (RCM): Researchers believe that many enterprises have implemented corporate governance under international practices, but have not caught up with other countries in the region and the world to increase competitiveness, not fast enough in responsiveness to today's volatile business environment (Vorhies \& Harker, 2000). Responsiveness to the change of the macro-environment shows how businesses monitor changes in the business environment to seize business opportunities and barriers (Srivastava et al., 2001).

(9) Financial capability (FC): Enterprises' financial capability is reflected in capital size, ability to mobilize and use it, and financial management. Enterprises using capital effectively will help businesses reduce financial costs, generate high profits, thereby creating expanded reproductive capability, improving production capability, increasing in quantity as well as product quality (Kirikova, 2000). Financial capability is closely related to financial activities. Because financial activities will regulate cash flow in connection with raising capital, managing, and using capital to serve the business operation of the company (Picken, 2017).

(10) Innovation products-services capability (IPSC): The ability to innovate products and services represents the process of encouraging continuous innovation of products and services to create new value for businesses. It can propose new production processes, new products, or new ideas to increase the competitive advantage (Damanpour, 1991). Deshpandé and Farley (2004) argue that the introduction of new products or services to the market will reflect the creative capability of the business. According to Szeto (2000), businesses must continuously improve and develop new products to meet customer requirements and be the first-mover in the market.

(11) Organization service capability (OSC): The quality of products and services contributes to the success of the business in its efforts to build an image for its customers and fulfill its business goals. According to Parasuraman et al. (1988), one of the factors with which businesses create a foothold in the market is the ability to organize services to serve customers and create credibility in customers. The ability to organize service to meet customer requirements has also been assessed as an essential component of service quality in the studies by Karin (2001).

(12) Enterprise risk management (ERM): Enterprise Risk Management is the establishment of a systematic and principled process applied to strategic planning and application across the enterprise. Because it is impossible to eliminate risks, businesses apply the enterprise risk management model to detect events, assess and manage events that are likely to affect business goals. Businesses to minimize negative impacts and seize opportunities (Liebenberg \& Hoyt, 2003).

(13) Branding management (BM): O'Cass and Ngo (2011) came up with the concept of branding management as an antecedent of the firm capability of the company. It involves a group of activities such as communication and 
marketing programs in providing a brand sense that is relevant to customers. Merrilees et al. (2011) in its study described branding capabilities, including four approaches: defining brand meaning, using the brand as an activity tool, conveying consistent brand meaning, and receiving brand support from employees.

\subsection{Hypotheses and Theoretical Model}

According to Zhang et al. (2009), in addition to the quality of human resources, in today's rapidly changing business environment, the flexibility of employees is also a factor that creates a competitive advantage for businesses. Flexible human resources capable of handling all internal and external situations such as changes in demand volume and design according to customer requirements. This issue is also demonstrated by Francas et al. (2011); however, a flexible labor transition will affect better competitiveness. Hence, there was the first hypothesis;

H1: The human resource management capability has a positive impact on the competitiveness of the seafood exporting enterprise.

Studies of leadership at different levels (groups or organizations), include joint leadership (Hiller et al., 2006), distribution and sharing of leadership roles (Bolden, 2011), administrative decentralization (Avolio \& Bass, 1995), leading organizational capability (Van Velsor \& O'Connor Patricia, 2007), strategic direction (Morrill, 2010) and intellectual leadership (Sydänmaanlakka, 2003). According to Kivipõld and Vadi (2010), leadership at the organizational level is defined by the overall leadership ability to detect and respond to changes in the external environment by maintaining the organization's primary goals. Therefore, the research formed the basis for two hypotheses:

$\mathrm{H} 2$ : The vision and strategic leadership have a positive impact on the competitiveness of the seafood exporting enterprise.

H3: Organization capability has a positive impact on the competitiveness of the seafood exporting enterprise.

Marketing competence is built on four essential components: Customer responsiveness, Competitor responsiveness, Responsiveness to the change of the macro-environment, and Relationship quality. The two researchers also pointed out that the above components all meet VRIN standards, which are the factors that create a dynamic capability for businesses. The previous research results also showed that responding to customer needs, adapting to competitors, responding to markets is related to business result (Nguyen \& Barrett, 2006; Nguyen et al.,
2006). Marketing competence helps businesses implement marketing programs more effectively. It is this capability that will help businesses capture changes in customers' needs for products and services they provide, thereby having a basis for offering new and more appropriate products and services. Moreover, the relationship quality is one of the key factors to ensure the long-term relationship between the business and the customer. Therefore, this capability is associated with the creative capability of enterprises (Benedetto \& Crawford, 2008, Khoa et al., 2020). Therefore, the authors proposed four hypotheses related the marketing capability, including:

H4: Customer responsiveness capability has a positive impact on the competitiveness of the seafood exporting enterprise.

H5: Relationship quality has a positive impact on the competitiveness of the seafood exporting enterprise.

H6: Competitor responsiveness capability has a positive impact on the competitiveness of the seafood exporting enterprise.

H7: Responsiveness to the change of the macroenvironment has a positive impact on the competitiveness of the seafood exporting enterprise.

Innovation technology capability is proven to dominate the competitiveness of enterprises (Guan et al., 2006). Based on the actual seafood processing and export industry of this study, the application of machinery, factory systems, processing lines, research and development $(R \& D)$ are improved indispensable in the process of competition and increase strengths in the export market (Kocoglu et al., 2012; Lai \& Lin, 2012). Hence, the research proposed the hypothesis:

H8: Innovation technology capability has a positive impact on the competitiveness of the seafood exporting enterprise.

Financial capability has a strong influence on the performance of commercial banks (Baral, 2005; Kouser et al., 2011). Financial capability is the most critical factor determining the ability of production as well as a leading indicator to assess the size of the business. Distribution channel establishment and advertising for products also need to be calculated and decided based on the financial status of the business. It is easy to attract other investors to contribute capital, and also earn consumers' trust. Enterprises that cannot afford to be acquired by powerful competitors or withdraw from the market by themselves. The research proposed the following hypothesis:

H9: Financial capability has a positive impact on the competitiveness of the seafood exporting enterprise. 
Innovation products-services capability is a means to achieve innovation in services and products in business strategy. This capability is to express the desire of enterprises to overcome the inconsistent practices and habits in business and pursuing business ideas, in line with competition requirements in the market (Menguc \& Auh, 2006), thereby changing businesses. The innovative capability of a business is higher than that of other enterprises in the industry, which will have higher competitiveness and capability of innovation products-services have a positive impact on the business results (Hult et al., 2004; Fernández-Mesa et al., 2013). The following hypothesis is proposed:

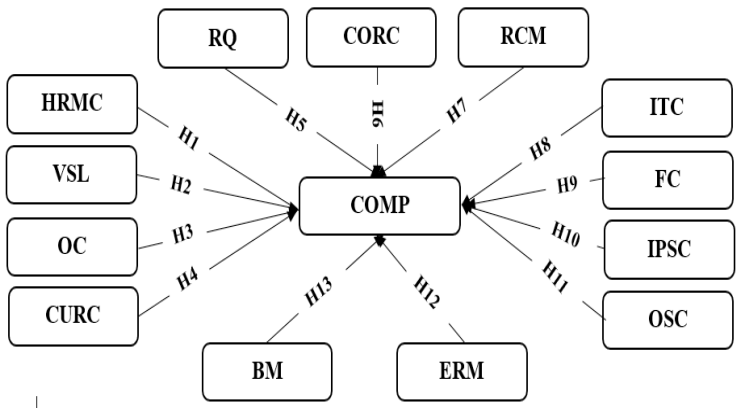

Figure 1: The conceptual model

H10: Innovation products-services capability has a positive impact on the competitiveness of the seafood exporting enterprise.

The service quality of a well-organized enterprise will create a competitive advantage to bring the products to customers faster and more efficiently (Parasuraman et al., 1988; Karatepe et al., 2005; Tahir \& Abu Bakar, 2007). Sales staff equipped with the knowledge of products and services will be able to satisfy customers' expectations in every transaction and thereby shape the culture of the exporting business and make a difference from the competitor. Consequently, the research proposed the hypothesis:

H11: Organization service capability has a positive impact on the competitiveness of the seafood exporting enterprise.

Lamarque (2005) emphasized that the profitability of a bank depends on the coordination of risk management in value chain activities. Proper risk management means that businesses control, prevent and limit the causes of risks. As a result, businesses will have a safe and efficient business environment. Risk management will help businesses minimize, minimize costs to overcome losses, risks, and as a result, the profits of the business will increase. Meanwhile, businesses can use that profit to reinvest, expand operations, and research the market. On the other hand, businesses will be able to stabilize operations and continue to overgrow.
Therefore, the enterprise risk management can be an antecedent of competitiveness:

H12: Enterprise risk management has a positive impact on the competitiveness of the seafood exporting enterprise.

The ability to build a brand is hard to copy and deliver, thus providing a sustainable competitive advantage (Morgan et al., 2009). Branding protects innovation from imitating competitors as well as allowing companies to manage risks efficiently and respond faster and more effectively to changes in the market (Lei et al., 2013; Khoa, 2020). From the evidence as mentioned above, this research will test the relationship between the ability to build brands and the competitiveness of seafood exporting businesses.

H13: Branding management has a positive impact on the competitiveness of the seafood exporting enterprise.

Figure 1 displays a conceptual model of this research, with Competitiveness (COMP), Human resources management capability (HRMC), Vision and strategic leadership (VSL), Organization capability (OC), Customer responsiveness capability (CURC), Relationship quality (RQ), Competitor responsiveness capability (CORC), Responsiveness to the change of the macro-environment (RCM), Innovation technology capability (ITC), Financial capability (FC), Innovation products - services capability (IPSC), Organization service capability (OSC), Enterprise risk management (ERM), Branding management (BM)

Table 1: The sample descriptive result

\begin{tabular}{|c|c|c|c|}
\hline & & $\mathbf{N}$ & $\%$ \\
\hline \multirow{2}{*}{$\begin{array}{l}\text { Level of } \\
\text { education }\end{array}$} & Bachelor & 123 & 35.14 \\
\hline & $\begin{array}{c}\text { Post } \\
\text { graduated }\end{array}$ & 227 & 64.86 \\
\hline \multirow{3}{*}{$\begin{array}{l}\text { Working } \\
\text { seniority } \\
\text { (year) }\end{array}$} & $<5$ & 31 & 8.86 \\
\hline & $5-10$ & 132 & 37.71 \\
\hline & $>10$ & 187 & 53.43 \\
\hline \multirow{4}{*}{$\begin{array}{l}\text { Management } \\
\text { seniority } \\
\text { (year) }\end{array}$} & $<2$ & 12 & 3.43 \\
\hline & $2-5$ & 19 & 5.43 \\
\hline & $5-10$ & 143 & 40.86 \\
\hline & $>10$ & 176 & 50.29 \\
\hline \multirow{2}{*}{$\begin{array}{l}\text { Type of } \\
\text { business }\end{array}$} & $\begin{array}{l}\text { Public } \\
\text { company }\end{array}$ & 167 & 47.71 \\
\hline & $\begin{array}{l}\text { Private } \\
\text { company }\end{array}$ & 183 & 52.29 \\
\hline \multirow{4}{*}{$\begin{array}{l}\text { Size of } \\
\text { business } \\
\text { (Number of } \\
\text { employees) }\end{array}$} & $<20$ & 46 & 13.14 \\
\hline & $20-50$ & 178 & 50.86 \\
\hline & $50-100$ & 69 & 19.71 \\
\hline & $>100$ & 57 & 16.29 \\
\hline
\end{tabular}


Table 2: The measurement scales

\begin{tabular}{|c|c|}
\hline Coding & Content \\
\hline HRMC1 & The ability to manage human resources effectively to achieve revenue and output goals of the business \\
\hline HRMC2 & Always planning the annual human resources according to the business plan. \\
\hline HRMC3 & Always create conditions for the development of staff competencies. \\
\hline VSL1 & The vision of the business is apparent and inspires employees. \\
\hline VSL2 & Actively motivate and encourage employees to understand the business's vision. \\
\hline VSL3 & Continuously monitor the effect of growth in sales and resources (capital, human resources...). \\
\hline VSL4 & Thinking of expanding export markets and showing a good understanding of international markets \\
\hline OC1 & Building an efficient and flexible organizational structure suitable for the size of enterprises \\
\hline $\mathrm{OC2}$ & Building culture (working style) is always innovating and continuously advancing in the enterprise. \\
\hline OC3 & Strong commitment to creating continuous learning opportunities for individuals. \\
\hline CURC1 & Regularly maintain relationships with local departments to find market information and customers. \\
\hline CURC2 & Ability to capture customer needs of businesses well \\
\hline CURC3 & Perform market research regularly to collect information about customers. \\
\hline CURC4 & Regularly interact with customers to understand their needs for the new SPDV. \\
\hline RQ1 & Establishing relationships with distributors. \\
\hline RQ2 & Establishing a relationship with customers. \\
\hline RQ3 & Establishing relationships with suppliers. \\
\hline RQ4 & Establish relationships with local authorities. \\
\hline RQ5 & Establishing relationships with credit and lending institutions. \\
\hline CORC1 & Regularly analyze the information about competitors. \\
\hline CORC2 & Analytical capabilities of strengths and weaknesses of competitors. \\
\hline CORC3 & Quickly implement plans related to competitors' changes. \\
\hline RCM1 & Regularly collect information on laws, taxes, business rules, economic situation. \\
\hline $\mathrm{RCM} 2$ & Information about changes in State policies is always exchanged and discussed. \\
\hline RCM3 & Always regulate business activities related to changing the business environment. \\
\hline ITC1 & Application of technology in product and service development. \\
\hline ITC2 & Continuously update the application of technology and technical improvement. \\
\hline ITC3 & Attention to equipment for research and development of products and services. \\
\hline ITC4 & Human resources for technology research and development are qualified. \\
\hline FC1 & Establish a reasonable financial structure to ensure business operations. \\
\hline $\mathrm{FC2}$ & Looking for capital for production and business activities. \\
\hline FC3 & Achieve capital adequacy levels according to the business objectives of the enterprise. \\
\hline IPSC1 & Research capability to continually innovate products and services according to market changes. \\
\hline IPSC2 & Make innovation to create new value for the business. \\
\hline IPSC3 & Implement innovations to expand the market and increase market share. \\
\hline BM1 & Registration of trademark ownership. \\
\hline BM2 & Promote promotional activities and public relations. \\
\hline BM3 & Promote advertising activities. \\
\hline OSC1 & Help and respond to customer requests \\
\hline OSC2 & Be polite with customer \\
\hline OSC3 & Gain customers' trust \\
\hline ERM1 & Apply technology in risk management \\
\hline ERM2 & Risk management knowledge and experience of managers meet job requirements. \\
\hline ERM3 & Organize regularly training courses to improve the risk management capability of the employee. \\
\hline
\end{tabular}




\section{Research Methods}

This study used a quantitative research method, which was conducted based on investigating the seafood exporting enterprises in Kien Giang province. The object of the investigation is one of the managers at these businesses. The sampling method for research is vital to ensure that the study is representative and the accuracy of the research results. It involves a sample of 350 seafood exporting enterprises in Kien Giang province, including public and private companies. The sample was selected by the simple random method with two attributes, including the size of the enterprise and the type of enterprise. In this research, the person who provides information represents the business that answers the survey questionnaires, i.e., the head and deputy of departments, the director, deputy director or those authorized by the director to participate in the leadership, task management, business administration tasks. The detailed sample result is present in Table 1 .

The measurement scale in this research was adapted from Porter's research $(1980,1990,2003)$ and Thompson, Strickland, Gamble (2006), and described as the statements with Likert scale ( 1 is the total disagree, and 5 is total agree). Table 2 shows the content of the measurement scale in the model.

\section{Empirical Results}

The first step is to assess the reliability of the scale before testing the scientific theory of the model (Hair et al., 2011). The survey results will be coded and used SPSS software to evaluate its reliability (Cronbach's Alpha) and exploratory factor analysis (EFA). Finally, the research will use the regression equation to determine the relationship between influencing factors and competitiveness, as well as assessing the influence of factors on competitiveness.

\subsection{Reliability Test}

The item with a Corrected Item - Total Correlation coefficient, is less than 0.3 , will be rejected. The construct will be reliable when Cronbach's Alpha coefficient of the scale is more significant than 0.7 (Nunnally \& Bernstein, 1994). However, it should be noted that Cronbach's Alpha is too high (more than 0.95); unnecessary items will likely appear on the scale.

Reliability test results of Cronbach's Alpha in Table 3 showed that 14 constructs (thirteen independent variables and one dependent variable) archived the reliability because Cronbach's Alpha coefficient is higher than 0.7), and all the Corrected Item - Total Correlation coefficient is higher than 0.3 . Thus, there are 14 constructs with 47 observable items used for exploratory factor analysis (EFA).

\subsection{Exploratory Factor Analysis (EFA)}

The EFA (Exploratory factor analysis) is used to shrink and summarize the data (Hair et al., 2010). In this analysis, the method of extracting Principal Axis Factoring elements with Promax rotation was used (Anderson \& Gerbing, 1988). Factor loading $>0.5$ is considered to be of practical significance. Besides, this method is based on the factor extraction factor (Eigenvalue), whereby factor extraction factor greater than 1.0 will be retained.

Table 3. The result of reliability

\begin{tabular}{|l|c|c|c|}
\hline \multicolumn{1}{|c|}{ Construct } & Items & Cronbach's Alpha & $\begin{array}{c}\text { The minimum of Corrected } \\
\text { Item - Total Correlation }\end{array}$ \\
\hline Human resources management capability (HRMC) & 3 & 0.768 & 0.563 \\
\hline Vision and strategic leadership (VSL) & 4 & 0.780 & 0.429 \\
\hline Organization capability (OC) & 3 & 0.921 & 0.434 \\
\hline Customer responsiveness capability (CURC) & 4 & 0.861 & 0.673 \\
\hline Relationship quality (RQ) & 5 & 0.927 & 0.64 \\
\hline Competitor responsiveness capability (CORC) & 3 & 0.767 & 0.543 \\
\hline $\begin{array}{l}\text { Responsiveness to the change of the macroenvironment } \\
\text { (RCM) }\end{array}$ & 3 & 0.765 & 0.732 \\
\hline Innovation technology capability (ITC) & 4 & 0.936 & 0.456 \\
\hline Financial capability (FC) & 3 & 0.922 & 0.564 \\
\hline Innovation products - services capability (IPSC) & 3 & 0.898 & 0.413 \\
\hline Branding management (BM) & 3 & 0.714 & 0.684 \\
\hline Organization service capability (OSC) & 3 & 0.868 & 0.543 \\
\hline Enterprise risk management (ERM) & 3 & 0.822 & 0.634 \\
\hline Competitiveness (COMP) & 3 & 0.845 & 0.567 \\
\hline
\end{tabular}


Table 4: The results of the EFA of thirteen independent variables

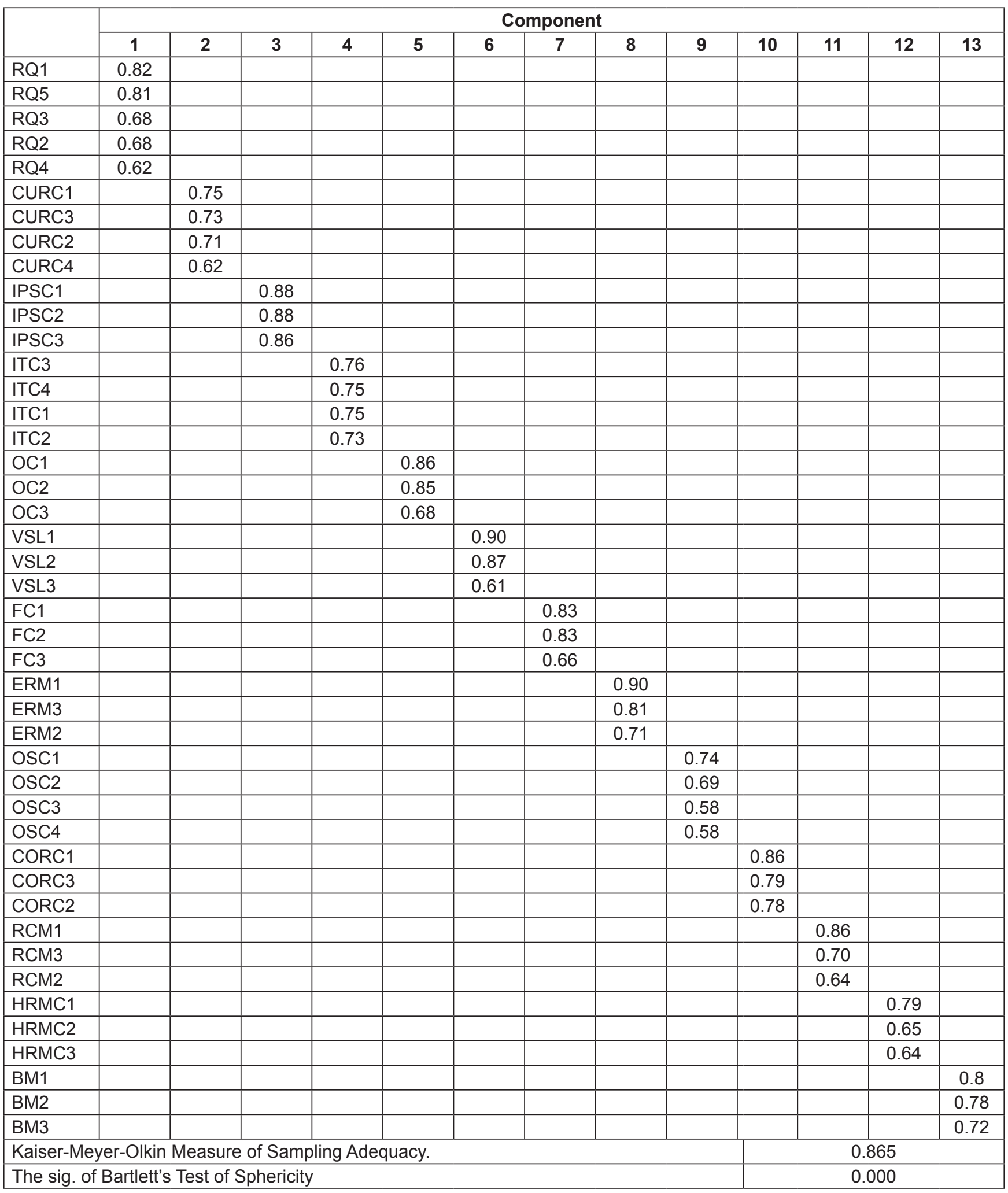


Minh Tuan NGUYEN, Bui Thanh KHOA /

Table 5: The results of EFA of the dependent variable

\begin{tabular}{|c|c|c|}
\hline No & & Component \\
\hline 1 & COMP2 & 0.906 \\
\hline 2 & COMP1 & 0.838 \\
\hline 3 & COMP3 & 0.837 \\
\hline \multicolumn{2}{|c|}{ Sig. } & 0.000 \\
\hline \multicolumn{2}{|c|}{ KMO } & 0.684 \\
\hline & \% of variance & 2.224 \\
\hline
\end{tabular}

In Table 4, the scale is accepted when the total variance extracted $\geq 50 \%$. When the KMO coefficient within 0.5 to 1 , the EFA is appropriate. The significance of Bartlett test $\leq$ 0.05 , the observed item is correlated with each other in the whole (Anderson \& Gerbing, 1988). The results of the EFA of 13 independent variables in Table 4 showed that there are 44 observed items grouped into 13 factors. The factor loadings are greater than 0.5 , so the observed items are important in the factors; they have practical significance in statistical analysis. KMO is 0.865 , which is higher than 0.5 ; the EFA in accordance with the market data. Bartlett's test has a significant level of 0.000 , it is less than 0.05 ; hence, the observed items are correlated with each other in the overall scope. Eigenvalue value is 1.022, which is greater than 1.0. The variance extracted was equal to $77.942 \%$, indicating that thirteen factors explained $77.942 \%$ of the variation in the research data.

The results of EFA in Table 5 showed that there are three observed items grouped into one dependent factor. The factor loadings are greater than 0.5 , so the observed items are important in the factors; they have practical significance in statistical analysis. KMO is 0.684 , which is higher than 0.5, the EFA in accordance with the market data. Bartlett's test has a significant level is 0.000 , which is smaller than 0.05 , so the observed items are correlated with each other in the overall scope. Eigenvalue value is 2.224, which is higher than 1.0. The variance extracted was equal to $74.118 \%$, indicating that the dependent variable was explained by $74.118 \%$ of the variation in the research data.

\subsection{Regression Analysis}

Regression analysis was performed by the Enter method, and the variables were included at the same time to select based on the criteria for selecting the variables with a significance level is less than 0.05 . According to the regression analysis results, there is no relationship between ERM and COMP, as well as OSC and COMP, because the significance level is more than 0.05. At the same time, the analysis results in Table 6 show that the VIF indexes (Variance Inflation Factor) of the variables in the model is very small, with values from 1.202 to 2.397, which are less than 10. This result has shown that the regression model does not violate the multicollinear phenomenon; the research model has statistical significance.

The results in Table 6 pointed out that the $\mathrm{R}$ coefficient value is 0.904 , which indicated that the relationship between variables in the model is highly correlated. The regression report of the model shows that the value of R2 (R Square) is equal to 0.818 , which indicates that the $81.8 \%$ chance of Competitiveness due to factors in the research, with the Sig. of F test, is less than 0.05. According to the Durbin Watson analysis in Table 6, dL is 1.561 and $\mathrm{dU}$ is 1.791 , DurbinWatson coefficient $(\mathrm{d})=1.865$ are in the range $(1.791$; 2.209), so there is no autocorrelation phenomenon between the residuals in the model, the research model has statistical significance. In the Spearman test, the significance level of Spearman correlation coefficients between the independent variables and the absolute of the standardized residual values is more than 0.05 . Therefore, all variables ensure no variance of residual changes, and the model has statistical significance.

\subsection{Pearson Correlation Analysis}

Correlation analysis of eleven construct in Table 7 shows that all independent variables are correlated with dependent variables (COMP) at a 99\% confidence level. The COMP that is most strongly correlated to RQ with $\mathrm{r}=$ 0.778 , and the weakest correlated to BM with $r=0.412$. This strong correlation is expected because it is the tight, linear relationship between the variables that explain the effect on the model results.

After performing regression tests compared to the whole, the research model does not violate the test hypotheses and has statistical significance, the relationship between the dependent variable and eleven independent variables is shown in Eq.1:

$C O M P=-0.387+0.101 * H R M C+0.057 * O C+$
$104 * C U R C+0.299 * R Q+0.138 * I T C+0.053 * C O R C$
$0.066 * R C M+0.056 * F C+0.116 * V L S+0.062 * I P S C$ (Eq.1) 
Table 6: Results of regression analysis

\begin{tabular}{|c|c|c|c|c|c|c|c|c|}
\hline & \multicolumn{8}{|c|}{ Coefficients } \\
\hline & \multirow{2}{*}{$\begin{array}{l}\text { Model } \\
\text { B }\end{array}$} & \multicolumn{2}{|c|}{$\begin{array}{l}\text { Unstandardized } \\
\text { Coefficients }\end{array}$} & \multirow[t]{2}{*}{$\begin{array}{c}\text { Standardized } \\
\text { Coefficients }\end{array}$} & \multirow[t]{2}{*}{$t$} & \multirow{2}{*}{$\begin{array}{l}\text { Sig. } \\
\text { Tolerance }\end{array}$} & \multicolumn{2}{|c|}{ Collinearity Statistics } \\
\hline & & Std. Error & Beta & & & & VIF & \\
\hline \multirow{14}{*}{1} & (Constant) & -.387 & .120 & & -3.226 & .001 & & \\
\hline & HRMC & .101 & .031 & .102 & 3.250 & .001 & .550 & 1.818 \\
\hline & OC & .057 & .027 & .070 & 2.130 & .034 & .497 & 2.012 \\
\hline & CURC & . 104 & .033 & 106 & 3.136 & .002 & .472 & 2.119 \\
\hline & $R Q$ & .299 & .030 & .331 & 10.022 & .000 & .495 & 2.018 \\
\hline & ITC & .138 & .031 & .159 & 4.429 & .000 & .417 & 2.397 \\
\hline & CORC & .053 & .018 & .069 & 2.889 & .004 & .936 & 1.068 \\
\hline & RCM & .066 & .025 & .076 & 2.692 & .002 & .681 & 1.467 \\
\hline & FC & .056 & .027 & .069 & 2.109 & .036 & .500 & 2.000 \\
\hline & VLS & .116 & .034 & .129 & 2.432 & .003 & .532 & 1.325 \\
\hline & IPSC & .062 & .025 & .077 & 2.488 & .013 & .566 & 1.766 \\
\hline & OSC & .103 & .033 & .103 & 3.110 & .088 & .490 & 2.041 \\
\hline & ERM & .027 & .020 & .035 & 1.313 & .190 & .759 & 1.317 \\
\hline & BM & .060 & .023 & .067 & 2.616 & .009 & .832 & 1.202 \\
\hline \multicolumn{9}{|c|}{ R Square $=0.818 ;$ Adjusted R Square $=0.811$} \\
\hline \multicolumn{9}{|c|}{ Durbin-Watson $=1.865$} \\
\hline \multicolumn{9}{|c|}{$F=125.908 ;$ Sig. of $F$ test $(A N O V A)=0.000$} \\
\hline
\end{tabular}

Table 7: Pearson correlation analysis

\begin{tabular}{|l|c|c|c|c|c|c|c|c|c|c|c|c|}
\hline \multicolumn{2}{|l|}{} & HRMC & OC & CURC & RQ & ITC & CORC & RCM & FC & IPSC & VSL & BM \\
\hline $\begin{array}{l}\text { Pearson } \\
\text { Correlation (r) }\end{array}$ & COMP & .652 & .646 & .689 & .778 & .718 & .455 & .539 & .629 & .587 & .677 & .412 \\
\hline Sig. (1-tailed) & & .000 & .000 & .000 & .000 & .000 & .000 & .000 & .000 & .000 & .000 & .000 \\
\hline
\end{tabular}

\section{Discussion and Implications}

The regression results showed that eleven hypotheses $(\mathrm{H} 1, \mathrm{H} 2, \mathrm{H} 3, \mathrm{H} 4, \mathrm{H} 5, \mathrm{H} 6, \mathrm{H} 7, \mathrm{H} 8, \mathrm{H} 9, \mathrm{H} 10, \mathrm{H} 13)$ are accepted with $95 \%$ confidence level, and two hypotheses (H11, H12) are rejected. In particular, the impact level on COMP decreases in the following order (1) Relationship quality $(\mathrm{RQ})($ Beta $=0.331$, sig. $=0.000)$, (2) Innovation technology capability $($ ITC) $($ Beta $=0.159$, sig.$=0.000)$, (3) Vision and strategic leadership (VSL) (Beta $=0.129$, sig. $=0.003)$, (4) Customer responsiveness capability $($ CURC) $($ Beta $=0.106$, sig. $=0.002),(5)$ Human resources management capability $(\mathrm{HRMC})($ Beta $=0.102, \mathrm{sig} .=0.001)$, (6) Innovation products - services capability (IPSC) $($ Beta $=$ 0.007 , sig. $=0.013),(7)$ Responsiveness to the change of the macroenvironment $(\mathrm{RCM})($ Beta $=0.076$, sig. $=0.002),(8)$ Organization capability $(\mathrm{OC})($ Beta $=0.070$, sig. $=0.034)$, (9) Competitor responsiveness capability (CORC) $($ Beta $=$ 0.069 , sig. $=0.004)$ and Financial capability $(\mathrm{FC})($ Beta $=$ 0.069 , sig. $=0.036),(10)$ Branding management $(\mathrm{BM})($ Beta $=0.067$, sig. $=0.009$ ). The results of this research are in line with previous studies on the competitiveness theories of Porter (1980, 1990, 2003); and Thompson et al.(2006), as well as the practical researches, i.e., Francas et al. (2011), Cameli and Tishler (2004), Kivipõld \& Vadi (2013), Nguyen \& Barrett (2006); Nguyen, Kocoglu et al.(2012); Lai \& Lin (2012); Baral (2005); Kouser et al.(2011); Hult et al.(2004); Fernández-Mesa et al.(2013); Lei et al.(2013).

Two factors that do not affect the competitiveness of seafood exporting enterprises are Organization service 
capability $(\mathrm{OSC})(\mathrm{Beta}=0.103$, sig. $=0.088)$ and Enterprise risk management $(\mathrm{ERM})($ Beta $=0.035$, sig. $=0.190)$. The reason these two factors are not significant about the competitiveness of exporting enterprises is relatively easy to understand. Firstly, exporting activity serves partners outside a country; therefore, customers receive relatively few and unclear services. Moreover, businesses can cooperate with third parties in export activities such as sales agents, shipping companies, warehousing service, so the Organization service capability is not paid attention to by businesses. As for enterprise risk management capability, mainly seafood exporting enterprises in Kien Giang province are small and have no long-term strategic orientation; therefore, sales strategy, as well as human resources, are more appreciated than risk management strategies. Alternatively, if there is only a low level of risk management through brief terms in export contracts without a clear risk management system.

Seafood exporting enterprises need to maintain and expand good relationships with the local government, whereby trading by attending seminars and meetings. The business should develop plans to maintain good relationships with five parties, including farmers, businesses, government, scientists, and financial investors (banks). Enterprises should pay attention to investing in infrastructure, machinery, and equipment; continually updating new technology applications, and learn new techniques to increase productivity as well as competitiveness. The business should pay attention to investing and training human resources for technology research and development so that they can gain in-depth expertise. The technology, as mentioned above application solutions, is also the foundation for developing new technologies in manufacturing and processing export goods of enterprises in Kien Giang province. Building the electronic commerce website is a good way to introduce the business as well as reach the international market (Nguyen \& Khoa, 2019a)

In the current economic conditions, customers' marketing capability directly affects the export business results of enterprises. Therefore, businesses need to focus on and improve marketing capability. Exporters need to focus on participating in international trade fairs actively. The customers' information is very important to get the success of business (Nguyen \& Khoa, 2019b,c). The business should set up a market research and product development department to research customers 'need, tastes, and trends. Regarding customers, especially international customers, the exporting business should proactively contact them, timely solve customer questions and requirements, and improve customer care activities. Regularly survey and explore the fluctuations in the market to offer products that suit the current market needs implementing product innovations to create new added values for businesses. Strengthen research and product development. Product businesses need to maintain and continue to implement international food safety standards well to suit each general market area. In terms of the macro business environment, enterprises should set up a department to collect market information to keep up with the changes in economy, politics, society, technology, and weather.

The board of director should clarify the strategic vision of the business so that all employees understand and follow that vision, and be more active in promoting and encouraging employees to learn about the enterprise's vision and strategy. The leaders should pay attention to equip themselves with the necessary knowledge about export activities such as policies, state guidelines, and cultural practices in the international market. Excellent organization and management must first apply modern management methods that have been successfully applied by businesses in many countries around the world such as records management, ISO 9000 quality management. All branch employees follow a new business mindset. Also, to standardize and record the entire business process of the branch's primary operations.

Human resource management is the implementation of recruitment, training, and development of human resources. Businesses need to develop recruitment plans for each year. Develop action programs to promote creativity and selfpromote employee initiatives. Facilitate workers to improve their education. Through retraining, employees understand the nature of the job, master the professional skills, work responsibly and engage with the business. Research and adjust policies on income, benefits, rewards, promotions, and promotions to suit the integration conditions in order to maintain and develop professional human resources.

Exporting enterprises must have abundant capital and ensure functional capital mobilization. Therefore, businesses need to have an appropriate capital balance plan to ensure liquidity. Exporting enterprises need to improve their financial management capability. It is necessary to thoroughly handle bad debts, which affects the axial load situation. Besides, there is a need to improve management to limit lending to new bad debts. Always focus on raising good capital before thinking about borrowing.

Lastly, businesses always research and build brands to create a reputation. A strong brand is a useful tool to increase the competitiveness of exporters. They are continuing to implement the image promotion well, creating and empowering existing positions and brands by advertising on television, newspapers, Internet, etc., promoting, propagating and sponsoring great shows. Communication is associated with social security activities to expand the business, enhance the position, prestige and brand at home and abroad. It is necessary to build a unique culture by implementing a professional communication style for administrators and 
employees, establishing some behaviors in dealing with customers and international partners.

\section{Limitations and Future Research}

All studies have limitations. This study also has specific limitations. Firstly, it aimed to test the seafood export industry in the context of An Giang province, Vietnam. The research results are not universal for the whole seafood export industry. Therefore, studies are needed to test this model in other areas or on a national scale to increase the generality of the research model. This study assessed the competitiveness of exporting enterprises without customer reviews. It is still subjective from the perspective and perceptions of business executives. On the other hand, the survey object is the director of the business, so in the subsequent studies, it is necessary to expand the survey object, including middlelevel managers, to have more accurate information about perceptions of competitiveness.

\section{Reference}

Ambrosini, V., \& Bowman, C. (2009). What are dynamic capabilities and are they a useful construct in strategic management? International Journal of Management Reviews, 11(1), 29-49. https://doi.org/10.1111/j.1468-2370.2

Anderson, J. C., \& Gerbing, D. W. (1988). Structural equation modeling in practice: A review and recommended two-step approach. Psychological Bulletin, 103(3), 411-423. https://doi. org/10.1037//0033-2909.103.3.411

Avolio, B. J., \& Bass, B. M. (1995). Individual consideration viewed at multiple levels of analysis: A multi-level framework for examining the diffusion of transformational leadership. The Leadership Quarterly, 6(2), 199-218. https:// doi.org/10.1016/1048-9843(95)90035-7

Baral, K. J. (2005). Health check-up of commercial banks in the framework of CAMEL: A case study of joint venture banks in Nepal. Journal of Nepalese Business Studies, 2(1), 41-55. https://doi.org/10.3126/jnbs.v2i1.55

Benedetto, D. C. A. \& Crawford, C. M. (2008). New Products Management (9th edition). Burr Ridge, IL: Irwin/McGrawHill.

Bolden, R. (2011). Distributed leadership in organizations: A review of theory and research. International Journal of Management Reviews, 13(3), 251-269. https://doi.org/10.1111/j.14682370.2011.00306.x

Carmeli, A., \& Tishler, A. (2004). The relationships between intangible organizational elements and organizational performance. Strategic Management Journal, 25(13), 12571278. https://doi.org/10.1002/smj.428

Damanpour, F. (1991). Organizational innovation: A metaanalysis of effects of determinants and moderators. Academy of Management Journal, 34(3), 555-590. https://doi. org/10.5465/256406

Day, G. S. (1994). The capabilities of market-driven organizations. Journal of Marketing, 58(4), 37-52. https://doi. org/10.1177/002224299405800404

Deshpandé, R., \& Farley, J. U. (2004). Organizational culture, market orientation, innovativeness, and firm performance: an international research odyssey. International Journal of Research in Marketing, 21(1), 3-22. https://doi.org/10.1016/j. ijresmar.2003.04.002

Fernández-Mesa, A., Alegre-Vidal, J., Chiva-Gómez, R., \& Gutiérrez-Gracia, A. (2013). Design management capability and product innovation in SMEs. Management Decision, 51(3), 547-565. https://doi.org/10.1108/00251741311309652

Francas, D., Löhndorf, N., \& Minner, S. (2011). Machine and labor flexibility in manufacturing networks. International Journal of Production Economics, 131(1), 165-174. https://doi. org/10.1016/j.ijpe.2010.03.014

Guan, J. C., Yam, R. C., Mok, C. K., \& Ma, N. (2006). A study of the relationship between competitiveness and technological innovation capability based on DEA models. European Journal of Operational Research, 170(3), 971-986. https://doi. org/10.1016/j.ejor.2004.07.054

Hair, J. F., Anderson, R. E., Babin, B. J., \& Black, W. C. (2010). Multivariate data analysis: A global perspective (Vol. 7). Saddle River, NJ: Pearson.

Hennig $\square$ Thurau, T., \& Klee, A. (1997). The impact of customer satisfaction and relationship quality on customer retention: A critical reassessment and model development. Psychology \& Marketing, 14(8), 737-764. https://doi.org/10.1002/ (SICI)1520-6793(199712)14:8<737::AID-MAR2>3.0.CO;2-F

Hiller, N. J., Day, D. V., \& Vance, R. J. (2006). Collective enactment of leadership roles and team effectiveness: A field study. The Leadership Quarterly, 17(4), 387-397. https://doi. org/10.1016/j.leaqua.2006.04.004

Ho, C. K. (2005). Corporate governance and corporate competitiveness: an international analysis. Corporate Governance: An International Review, 13(2), 211-253. https:// doi.org/10.1111/j.1467-8683.2005.00419.x

Homburg, C., Grozdanovic, M., \& Klarmann, M. (2007). Responsiveness to customers and competitors: the role of affective and cognitive organizational systems. Journal of Marketing, 71(3), 18-38. https://doi.org/10.1509/jmkg.71.3.018

Hult, G. T. M., Hurley, R. F., \& Knight, G. A. (2004). Innovativeness: Its antecedents and impact on business performance. Industrial marketing management, 33(5), 429-438. https://doi. org/10.1016/j.indmarman.2003.08.015

Karatepe, O. M., Yavas, U., \& Babakus, E. (2005). Measuring service quality of banks: Scale development and validation. Journal of Retailing and Consumer Services, 12(5), 373-383. https://doi. org/10.1016/j.jretconser.2005.01.001

Karin, N. (2001). Interrogating SERVQUAL: a critical assessment of service quality measurement in a high street retail bank. The 
International Journal of Bank Marketing, 19(3), 126-139. https://doi.org/10.1108/02652320110388559

Karim, M. A., Smith, A. J. R., Halgamuge, S. K., \& Islam, M. M. (2008). A comparative study of manufacturing practices and performance variables. International Journal of Production Economics, 112(2), 841-859. https://doi.org/10.1016/j. ijpe.2007.07.005

Khoa, B. T. (2020). The Antecedents of Relationship Marketing and Customer Loyalty: A Case of the Designed Fashion Product. Journal of Asian Finance, Economics and Business, 7(2), 195204. https://10.13106/jafeb.2020.vol7.no2.195

Khoa, B. T., Nguyen, T. D., \& Nguyen, V. T. T. (2020). Factors affecting Customer Relationship and the Repurchase Intention of Designed Fashion Products. The Journal of Distribution Science, 18 (2), 17-28. https://10.15722/jds.18.2.202002.17

Kim, W. C. (2005). Blue ocean strategy: from theory to practice. California Management Review, 47(3), 105-121. https://doi.org/10.1177/000812560504700301

Kirikova, M. (2000). Explanatory capability of enterprise models. Data \& Knowledge Engineering, 33(2), 119-136. https://doi.org/10.1016/S0169-023X(99)00048-8

Kivipõld, K., \& Vadi, M. (2010). A measurement tool for the evaluation of organizational leadership capability. Baltic Journal of Management, 5(1), 118-136. https://doi. org/10.1108/17465261011016595

Kivipõld, K., \& Vadi, M. (2013). Market orientation in the context of the impact of leadership capability on performance. International Journal of Bank Marketing, 31(5), 368-387. https://doi.org/10.1108/IJBM-09-2012-0092

Kocoglu, I., Imamoglu, S. Z., Ince, H., \& Keskin, H. (2012). Learning, R\&D and manufacturing capabilities as determinants of technological learning: enhancing innovation and firm performance. Procedia-Social and Behavioral Sciences, 58, 842-852. https://doi.org/10.1016/j.sbspro.2012.09.1062

Kohli, A. K., \& Jaworski, B. J. (1990). Market orientation: the construct, research propositions, and managerial implications. Journal of marketing, 54(2), 1-18. https://doi. org/10.1177/002224299005400201

Kouser, R., Aamir, M., Mehvish, H., \& Azeem, M. (2011). CAMEL analysis for Islamic and conventional banks: Comparative study from Pakistan. Economics and Finance Review, 1(10), 55-64.

Krasnikov, A., \& Jayachandran, S. (2008). The relative impact of marketing, research-and-development, and operations capabilities on firm performance. Journal of marketing, 72(4), 1-11. https://doi.org/10.1509/jmkg.72.4.001

Lai, Y. L., \& Lin, F. J. (2012). The effects of knowledge management and technology innovation on new product development performance an empirical study of Taiwanese machine tools industry. Procedia-Social and Behavioral Sciences, 40, $157-$ 164. https://doi.org/10.1016/j.sbspro.2012.03.176

Lamarque, E. (2005). Identifying key activities in banking firms: a competence-based analysis. Competence Perspectives on Managing Internal Processes Advances in Applied
Business Strategy, 7, 29-47. https://doi.org/10.1016/S07496826(04)07002-7

Lall, S. (2001). Competitiveness indices and developing countries: an economic evaluation of the global competitiveness report. World development, 29(9), 1501-1525. https://doi. org/10.1016/S0305-750X(01)00051-1

Lei, X., Ye, T., \& Abimbola, T. (2013). The role of branding capability for innovative companies: Stock market reactions to new product announcement. Nankai Business Review International, 4(4), 329-348. https://doi.org/10.1108/NBRI-012013-0001

Liebenberg, A. P., \& Hoyt, R. E. (2003). The determinants of enterprise risk management: Evidence from the appointment of chief risk officers. Risk management and insurance review, 6(1), 37-52. https://doi.org/10.1111/1098-1616.00019

Lu, W., Shen, L., \& Yam, M. C. (2008). Critical success factors for competitiveness of contractors: China study. Journal of Construction Engineering and Management, 134(12), 972-982. https://doi.org/10.1061/(ASCE)0733-9364(2008)134:12(972)

Nguyen, T. D., \& Barrett, N. J. (2006). Internet-Based Knowledge Internalization and Firm Internationalization in Transition Markets. International Marketing Research, 17, 369-394. https://doi.org/10.1016/S1474-7979(06)17014-3

Nguyen, T. D., Barrett, N. J., \& Fletcher, R. (2006). Information internalization and internationalization - Evidence from Vietnamese firms. International Business Review, 15(6), 682701. https://doi.org/10.1016/j.ibusrev.2006.09.001

Nguyen, H. M., \& Khoa, B. T. (2019a). Perceived Mental Benefit in Electronic Commerce: Development and Validation. Sustainability, 11(23), 6587-6608. https://10.3390/su11236587

Nguyen, H. M., \& Khoa, B. T. (2019b). The Relationship between the Perceived Mental Benefits, Online Trust, and Personal Information Disclosure in Online Shopping. Journal of Asian Finance, Economics and Business, 6(4), 261-270. https://10.13106/jafeb.2019.vol6.no4.261

Nguyen, M. H., \& Khoa, B. T. (2019c). Customer Electronic Loyalty towards Online Business: The role of Online Trust, Perceived Mental Benefits and Hedonic Value. The Journal of Distribution Science, 17(12), 102-112. https://10.15722/ jds.17.12.201912.102

Nguyen, M.H., \& Ngoc, B.H. (2020). Energy Consumption Economic Growth Nexus in Vietnam: An ARDL Approach with a Structural Break. Journal of Asian Finance, Economics and Business, 7(1), 101-110. https://doi.org/10.13106/jafeb.2020. vol7.no1.101

Nguyen, M.H., Mai, L.T., \& Huynh, T.L. (2019). The Role of Transformational Leadership toward Work Performance through Intrinsic Motivation: A Study in the Pharmaceutical Field in Vietnam. Journal of Asian Finance, Economics and Business, 6(4), 201-212. https://doi.org/10.13106/jafeb.2019. vol6.no4.201

Nunnally, J. C., \& Bernstein, I. (1994). The assessment of reliability. Psychometric theory, 3(1), 248-292. 
Martin, L., Westgren, R., \& van Duren, E. (1991). Agribusiness competitiveness across national boundaries. American Journal of Agricultural Economics, 73(5), 1456-1464. https://doi. org/10.2307/1242402

Menguc, B., \& Auh, S. (2006). Creating a firm-level dynamic capability through capitalizing on market orientation and innovativeness. Journal of the Academy of Marketing Science, 34(1), 63-73. https://doi. org/10.1177/0092070305281090

Merrilees, B., Rundle-Thiele, S., \& Lye, A. (2011). Marketing capabilities: Antecedents and implications for B2B SME performance. Industrial Marketing Management, 40(3), 368375. https://doi.org/10.1016/j.indmarman.2010.08.005

Minot, N. (1998). Competitiveness of Food Processing in Vietnam: A Study of the Rice, Coffee, Seafood and Fruit and Vegetables Subsectors. Washington, DC: International Food Policy Research Institute.

Morgan, N. A., Vorhies, D. W., \& Mason, C. H. (2009). Market orientation, marketing capabilities, and firm performance. Strategic Management Journal, 30(8), 909-920. https://doi.org/10.1002/smj.764

Morrill, R. L. (2010). Strategic leadership: Integrating strategy and leadership in colleges and universities. Lanham: Rowman \& Littlefield Publishers, Inc.

O'Cass, A., \& Ngo, L. V. (2011). Achieving customer satisfaction in services firms via branding capability and customer empowerment. The Journal of Services Marketing, 25(7), 489496. https://doi.org/10.1108/08876041111173615

Parasuraman, A., Zeithaml, V. A., \& Berry, L. L. (1988). SERVQUAL: A multiple-item scale for measuring consumer perception of service quality. Journal of Retailing, 64(1), 1237.

Picken, J. C. (2017). From startup to scalable enterprise: Laying the foundation. Business Horizons, 60(5), 587-595. https://doi. org/10.1016/j.bushor.2017.05.002

Porter, M. E. (1980). Competition strategy: Techniques for analyzing industries and competitors. New York: The Free Press.

Porter, M. E. (1990). The competitive advantage of nations. Harvard Business Review, 68(2), 73-93. https://doi.org/10.1007/978-1349-11336-1

Porter, M. E. (2003). Building the microeconomic foundations of prosperity: Findings from the business competitiveness index. The global competitiveness report, 2004, 29-56.

Porter, M. E. (2008). On competition, Updated and Expanded Edition. Boston, MA: Harvard Business School Publishing.
Rojalka, J. (2009). Baltic States' competitiveness: before and after the global crisis. Applied Economics: Systematic Research, 3(1), 27-46.

Salloum, M. (2013). Explaining the Evolution of Performance Measures-A Dual Case-Study Approach. Journal of Engineering, Project, and Production Management, 3(2), 99106. https://doi.org/10.32738/JEPPM.201307.0006

Schwab, K. (2019). The global competitiveness report 2019. Geneva: World Economic Forum. Retrieved from http://www3.weforum. org/docs/WEF_TheGlobalCompetitivenessReport2019.pdf.

Smith, J. B. (1998). Buyer-seller relationships: similarity, relationship management, and quality. Psychology \& Marketing, 15(1), 3-21. https://doi.org/10.1002/(SICI)15206793(199801)15:1<3::AID-MAR2>3.0.CO;2-I

Srivastava,R.K.,Fahey,L.,\&Christensen,H.K.(2001). Theresourcebased view and marketing: The role of market-based assets in gaining competitive advantage. Journal of management, 27(6), 777-802. https://doi.org/10.1177/014920630102700610

Sydänmaanlakka, P. (2003). Intelligent leadership and leadership competencies: Developing a leadership framework for intelligent (Doctoral dissertation). Department of Industrial Management, Helsinki University of Technology, Finland.

Szeto, E. (2000). Innovation capacity: working towards a mechanism for improving innovation within an interorganizational network. The TQM Magazine, 12(2), 149-158. https://doi.org/10.1108/09544780010318415

Tahir, I. M., \& Abu Bakar, N. M. (2007). Service quality gap and customers' satisfactions of commercial banks in Malaysia. International Review of Business Research Papers, 3(4), 327-336.

Thompson, A. A., \& Strickland, A. J., \& Gamble, J. (2006). Strategic management: Concepts and cases. Maidenhead: McGraw-Hill Education.

Van Velsor, E., \& O'Connor Patricia, M. G. (2007). Developing Organizational Capacity for Leadership.In: H. Robert, G. H. James, A. John, B. B. Kimberly, \& L. Nancy (Eds.), Being There Even When You Are Not (Vol. 4, pp. 31-49). United Kingdom: Emerald Group Publishing Limited. https://doi.org/10.1016/ S1479-3571(07)04002-3

Vorhies, D. W., \& Harker, M. (2000). The capabilities and performance advantages of market-driven firms: An empirical investigation. Australian journal of management, 25(2), 145171. https://doi.org/10.1177/031289620002500203

Zhang, Q., Vonderembse, M. A., \& Cao, M. (2009). Product concept and prototype flexibility in manufacturing: Implications for customer satisfaction. European Journal of Operational Research, 194(1), 143-154. https://doi.org/10.1016/j.ejor.2007.12.013. 